\title{
Characters of Ancient Architectural Orders and their Mannerist Interpretation in Dietterlin's Book from 1598
}

\author{
By Vladimir Mako*
}

\begin{abstract}
The aim of this paper is to explore a particular metaphorical pictorial language used by German mannerist painter Wendel Dietterlin in his book on architecture at the end of the sixteenth century. It was formed through personal imaginary interpretation of the Vitruvian notion regarding personal characters of the five ancient architectural Orders. In that context it has all aspects of the mannerist approach in inventing metaphorical meanings by combining ancient, mediaeval, and contemporary narratives. However, in that process Dietterlin unavoidably refers to cultural and social aspects of his time, particularly when reflecting on the issue of the invention of the 'new [German] architecture'. By this, Dietterlin enters the group of the majority of German sixteenth and seventeenth century authors on architecture emphasizing one particular prerogative in their writings: to merge the ancient roots with the longing for a coherent German cultural identity. However, it seems that in the process of narration, used to 'invent' new forms of architectural expression, Dietterlin refers also on particularities related to the historical development of mankind in a personal manner.
\end{abstract}

\section{Introduction}

The sixteenth and seventeenth century German culture marks an intensive appearance of treatises dealing with the art of architecture. Mostly they are introducing characteristics of five classical Orders, based on the Vitruvian and Italian Renaissance tradition, and supplemented with new ideas regarding contemporary (German) architecture. However, the ideas of what contemporary architecture based on the ancient tradition can be, developed in a particular sense of creation of new forms. In that sense, German examples seems to follow the general attitude developed in Italy and other neighboring countries, that architectural design applies more to the idea of intuitional invention than rational thinking. In that context the Italian term 'Invenzione' transformed into expression where personal experiences took the essential role in conceptualizing architectural ideas. $^{1}$

The very essence of such creative impulse opposite to the Renaissance design concept, has been accurately defined by Rykwert in his opinion that "the architecture of the sixteenth century could not simply make its appeal to nature and reason, or base its procedure on the operations of reason prompted by philosophy; in the sixteenth century rules which had to have the sanction of grace,

*Professor, Faculty of Architecture, University of Belgrade, Serbia.

1. J. Ackerman, "The Tuscan/Rustic Order: A Study in the Metaphorical Language of Architecture," Journal of the Society of Architectural Historians 42, no.1 (1983), 22. 
had to be derived from, guaranteed by divine revelation." ${ }^{2}$ In that sense we should speak rather of a creative development under the influence of personal artistic sensibility than of a model based on analytical approach to ancient tradition. In that context we should mention two German authors which work indicates the change of interest from a structural approach to art of building developed in Italian Renaissance, towards decoration as a dominant aspect in cultural evaluation of architecture. The book published by Blum in 1560 presents exclusively proportions and ornaments applied on details of the entablature of five Orders, and Stoer in his engravings from 1567 used the decorative forms of scrollwork as fundamental element of architectural creation. ${ }^{3}$ In that sense and mainly through their sensibility for pictorial values they magnified the importance of decoration as the essence of architectural expression, which as an idea was already generally developed in German art and culture of the time. Probably that was the reason way the majority of historians defined the sixteenth century in the north Europe, particularly in Germany, as an epoch of decorative art. ${ }^{4}$ It seems that in such context visually presented ideas could also develop a particular narrative expression and easy understandable metaphors rooted in common contemporary culture.

One of such works is undoubtedly the treatise on architectural Orders published by Wendel Dietterlin in $1598 .^{5}$ The main characteristics of this work are already noted and presented by a few scholars, showing that Dietterlin's approach to the composition of his book was predominantly guided by mannerist understanding of personal creativity. Establishing his ideas almost exclusively on engravings, he interpreted the five Orders moving into particular personal narrative form of expression. In that sense, Dietterlin "considered the Orders as catalysts rather than prescriptive rules," ${ }^{6}$ and shifting his interpretation far from Vitruvian and Renaissance tradition by merging Christian themes and classical mythological personalities and stories. ${ }^{7}$ Nevertheless, it seems that such approach to different traditions could be recognized as usual in German sixteenth century culture. ${ }^{8}$ That notion is from particular importance for our discussion while it

2. J. Rykwert, On Adam's House in Paradise: the Idea of the Primitive Hut in Architectural History (Cambridge, Mass.: The MIT Press, 1981), 120.

3. H. Blum, Ein Kunstreych Buch von Allerley Antiquiteten, so zum Verstand der Funf Seulen der Architectur Gehorend (Zurich, Froschower, 1560); L. Stoer, Geometria et perspective (Augsburg: Hans Rogel, 1567).

4. E. Forssman, Saule und Ornament: Studien zum problem des Manierismus in den nordischen Saulenbuchern und Vorlageblattern des 16. und 17. Jahrhunderts (Uppsala: Almqvist \& Wiksells, 1956), 11-14.

5. W. Dietterlin, Architectura von Ausstheilung/Symetria und Proportion der Funff Seulen/ und aller darauss volgender Kunst Arbeit von Fenstern/Caminen/Thurgerichten/Portalen/Bronen und Epitaphien (Nuremberg: Caymox, Balthasar, 1589).

6. K. Skelton, "Shaping the Book and the Building: Text and Image in Dietterlin's 'Architectura," Work \& Image 23, no.1 (2007): 29.

7. H. W. Kruft, A History of Architectural Theory from Vitruvius to the Present (New York: Princeton Architectural Press, 1994), 169; Forssman, Saule und Ornament: Studien zum Problem des Manierismus in den Nordischen Saulenbuchern und Vorlageblattern des 16. Und 17. Jahrhunderts, 1956, 160.

8. M. Kurt, "Den Maler, Wendel Dietterlin," in Festschrift fur Karl Lohmeyer (ed.) Karl Schwingel (Saarbrücken: West-Ost-Verlag, 1954), 18. 
opens the possibility that Dietterlin's personally developed metaphors are reflecting on accepted cultural narratives of his time.

In Dietterlin's book there are notions regarding a more structural role of decoration in actualizing observer's sense in differentiating levels of social and cultural importance of architecture. Reflecting on that issue, Forssman's notion that "decoration made house a city hall" identifies the potential that decorative expression in architecture could be used in establishing social and cultural meanings. ${ }^{9}$ Consequently, it seems that through the approach to the field of art of building, Dietterlin pervades a sense of a complex relationship among different artistic expressions, using their narrative potential in offering new visions and meanings of contemporary culture.

In that context, we should emphasize the possibility that such complexity of cultural narrative emerged from his consideration of five Orders rather as essentially meaningful characters, than as pure architectural masses. ${ }^{10}$ This notion would be based on Dietterlin's active development of Vitruvian and Renaissance metaphors regarding the identification of five Orders with human characters. In that context, we should emphasize once more that the main artistic media through which Dietterlin formed his metaphorical ideas was sculpture, with carefully chosen figures according to their mythological meaning. That is the reason why in our discussion we will pay attention particularly on engravings shaped through metaphorical narrative based on sculptural compositions incorporated into architectural presentation of Orders.

At the beginning of our discussion regarding metaphors that Dietterlin developed as his vision of each Order's character, we should briefly pay attention on a few important aspects essential for the general structure of the book. In two introduction texts, the longest ones in the whole book, Dietterlin mainly emphasizes that the focus of his presentations reflects on symmetry and proportions of all named and depicted architectural elements. ${ }^{11}$ By that Dietterlin the painter builds his essential notion on architecture by emphasizing the importance of proportion, symmetry, and consequently geometry as creative tools in all arts, developed in European and particularly German sixteenth century culture. ${ }^{12}$ In that context at the beginning of each book on a particular Order, he introduces proportional regulations of columns and entablature with all necessary differences that belong to their particular characters. There is a probability that Dietterlin's depictions of proportional regulations have been under the Serlio's influence. ${ }^{13}$ However, one can think on even more essential engagement of Italian master's ideas reflecting on existence of perfectly proportioned architectural

9. Ibid, 13.

10. Forssman Saule und Ornament: Studien zum Problem des Manierismus in den Nordischen Saulenbuchern und Vorlageblattern des 16. Und 17. Jahrhunderts, 1956, 162.

11. Dietterlin, Architectura von Ausstheilung/Symetria und Proportion der Funff Seulen/und aller darauss volgender Kunst Arbeit von Fenstern/Caminen/Thurgerichten/Portalen/Bronen und Epitaphien, 1589, 2-3.

12. V. Mako, "Lorenz Stoer and the Metaphor of Creative Power in Architecture," Athens Journal of Architecture 4, no.1 (2018): 65-84.

13. M. Adamska, Wendel Dietterlin Starszy: Jego Architectura von Austheilung Z.R. 1598 (Krakowie: PAN i PAN, Recynik Biblioteki Naukovej, Rok XLVIII, 2003), 448. 
elements as universal values. In the first book on Tuscan Order, at the beginning of the section presenting portals, Dietterlin in the engraving 23 gives a schematic proportional and compositional depiction of a perfected ideal example mainly used on all portals in the book. It proves his understanding that perfected proportional and compositional scheme forms universal essence of any architectural design despite of the factual materialization of details. Moreover, it seems that the compositional role of portals as the "backdrop of an ongoing scene" is from a particular importance. ${ }^{14}$

However, it would be an overstatement that Dietterlin followed precisely all ideas offered by Italian Renaissance architects. His variable approach to the issue of ancient Orders and their essential characteristics as cultural metaphors is evident at the very beginning of the book on the Tuscan Order.

\section{Tuscan Order}

Architectural historians, dealing with the origin and characteristics of the Tuscan Order, usually refer on Serlio's notions regarding the issue. ${ }^{15}$ In that context, his comment that the Tuscan Order is the first in line among other four because it is the most rustic one, have been taken as a key point relevant for general understanding of its essence. In a particular way this issue is important also for our discussion. Namely, in his short introduction on Tuscan Order, Dietterlin cites Plinius by stating that it is the oldest one in the first place, and just after that he is mentioning the Order's strength and roughness. ${ }^{16}$ More than that, Dietterlin gives a remark that the name of the Tuscan Order comes from the giant Tuscano, who was the father of Germans. ${ }^{17}$

This obscure comment, linking the oldest of five Orders and the primordial father of German people derives from an unknown source. However, it mainly indicates existence of a longing for national identification through art and architecture in the sixteenth century German culture and later. One can think that this longing was probably the impulse for Dietterlin's merging of ancient mythological and Christian religious aspects, as bearers of early European artistic tradition and contemporary German cultural forms. However, we should not neglect Dietterlin's mannerist artistic sensibility in shaping figures and their pictorial and compositional appearance, as an important part in expression of particular complexity and richness of metaphorical narration. This refers mostly on the column like figures placed on the first illustrative pages regarding each Order.

14. Skelton, "Shaping the Book and the Building: Text and Image in Dietterlin's 'Architectura,"” 2007, 27.

15 Ackerman, "The Tuscan/Rustic Order: A Study in the Metaphorical Language of Architecture," 1983, 15.

16 Dietterlin, Architectura von Ausstheilung/Symetria und Proportion der Funff Seulen/und aller darauss volgender Kunst Arbeit von Fenstern Caminen/Thurgerichten/Portalen/Bronen und Epitaphien, 1589, 5.

17 Ibid; Forssman, Saule und Ornament: Studien zum Problem des Manierismus in den Nordischen Saulenbuchern und Vorlageblattern des 16. und 17. Jahrhunderts, 1956, 163; Kruft, A History of Architectural Theory from Vitruvius to the Present, 1994, 169. 
They probably depict Dietterlin's primal notion regarding their architectural metaphorical characters.

Regarding the Tuscan Order, there is in engraving 6 a depiction of a male figure compounded out of a number of objects, vine and grapes. Human torso has been supplemented with a barrel as a trunk, wooden pail as a capital, spoon as forehead emblem, and decorated with a jug cut in half and placed between vine and grapes covering the lower part of the figure (Figure 1). Already at the first glance it shows that this interpretation, essentially associated with Tuscan Order, is far from reflecting on military and protective function - an idea developed in Italian Renaissance of the sixteenth century. ${ }^{18}$ Its rudimentary appearance directs our attention more on human impulse for satisfying elementary worldly needs for eating and drinking, than on higher cultural and ethical aspects. However, standing far from a classical form of Bacchus, this figure looks more as a German contemporary depiction of an innkeeper.

Nevertheless, in the serial of compositions of Tuscan portals, we encounter two examples which are reflecting on the initial idea metaphorically presented in the analyzed figure. In the engraving 29, Dietterlin presented a rustic portal with a sculptural composition over the entrance. The composition consists on the figure of young Bacchus surrounded with jugs and two male goats. In this example Dietterlin is aiming our attention directly to the ancient god of wine, marking the character of the Tuscan Order as the bearer of human elementary impulses. He repeats this notion in the next engraving (Figure 2). A man dressed as innkeeper is presented passing into the building, carrying dishes. The arch over the entrance is decorated with emblematic ornaments composed out of spoons and knives. Two figures of Pan in the lower zone are flanking the entrance. In the higher zone of the composition, on the right side a men playing the pan's flute is represented, and in the middle a figure identified as Cyclops Polyfem takes place. ${ }^{19}$

18. Ackerman, "The Tuscan/Rustic Order: A Study in the Metaphorical Language of Architecture," 1983, 15.

19. Forssman, Saule und Ornament: Studien zum Problem des Manierismus in den Nordischen Saulenbuchern und Vorlageblattern des 16. und 17. Jahrhunderts, 1956, 163. 


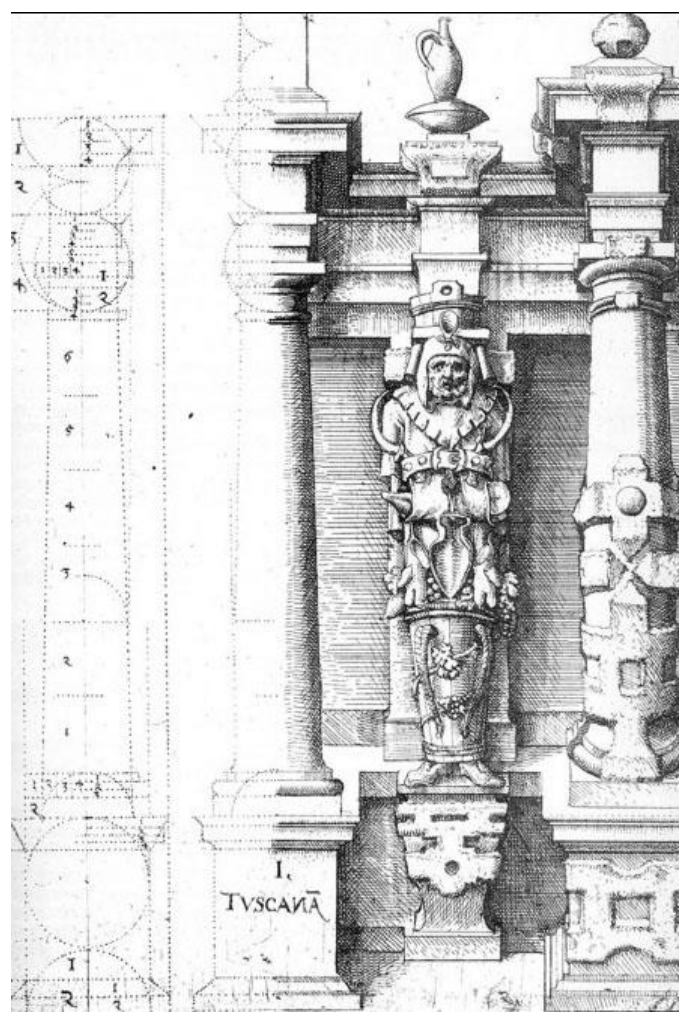

Figure 1. Dietterlin, Architectura, Engraving 6, 1598

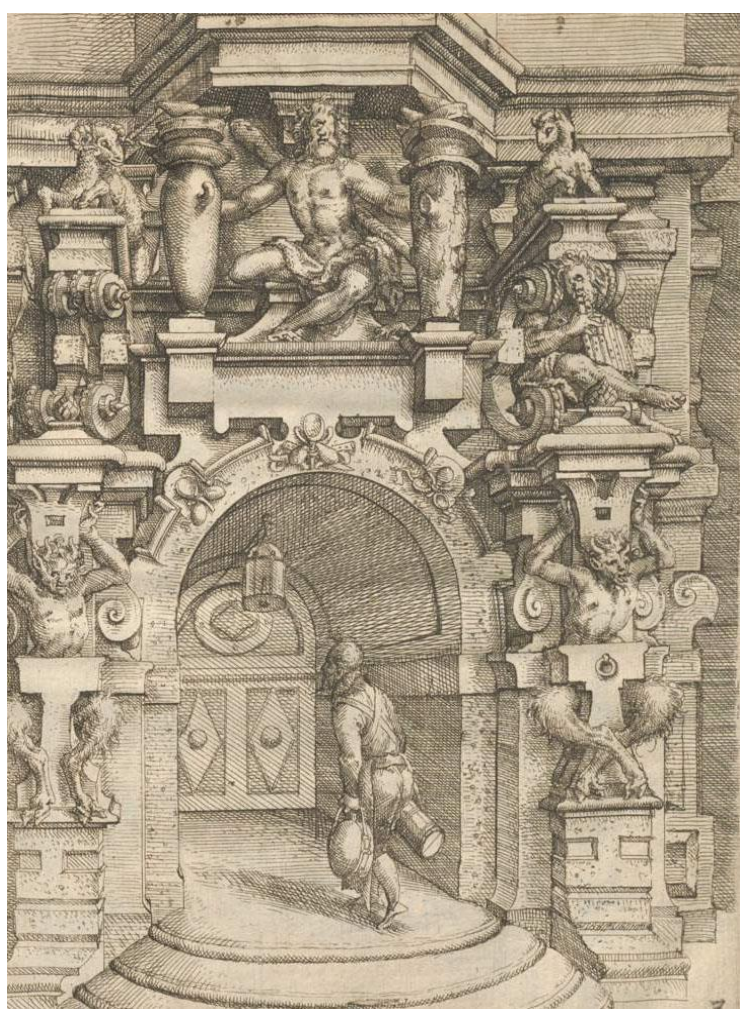

Figure 2. Dietterlin, Architectura, Engraving 30, 1598 
Presence of the mythological giant indicates development of Dietterlin's narrative in a particular way. It seems that through the idea of combining metaphors of elementary human needs with mythological characters from the beginning of the world's history he speaks of primordial content of human existence placing it within contemporary cultural context. That is probably the reason why in engraving 24, Dietterlin composed a portal which aims to illustrate the dawn of humankind, assembling figures of Adam, Eve, and their two sons, accompanied with a number of different animals, real and mythological (a unicorn on the left side of the portal).

The architectural form of the portal was materialized by using rough blocks of stone. However, it is not a representation of a ruin, but an idea of how one imagines rudimental use of stone in building (Figure 3). To this conclusion drives us the sense of primordial character of the scene, and particularly the disposition of portal's parts. They refer on geometrical perfectness outlined in the idealistic proportional scheme presented in engraving 23 (Figure 4). It underlines the idea that even architectural example belonging to primordial epoch and build in a raw material, should contain a divine spark - proportion and geometry as the essence of world's harmony. People's basic impulses and living habits are equalized with the mythological time. Through the presence of divine laws of harmony they become parts of one entirety, which also reflects through the first and oldest ancient Order, the Tuscan.

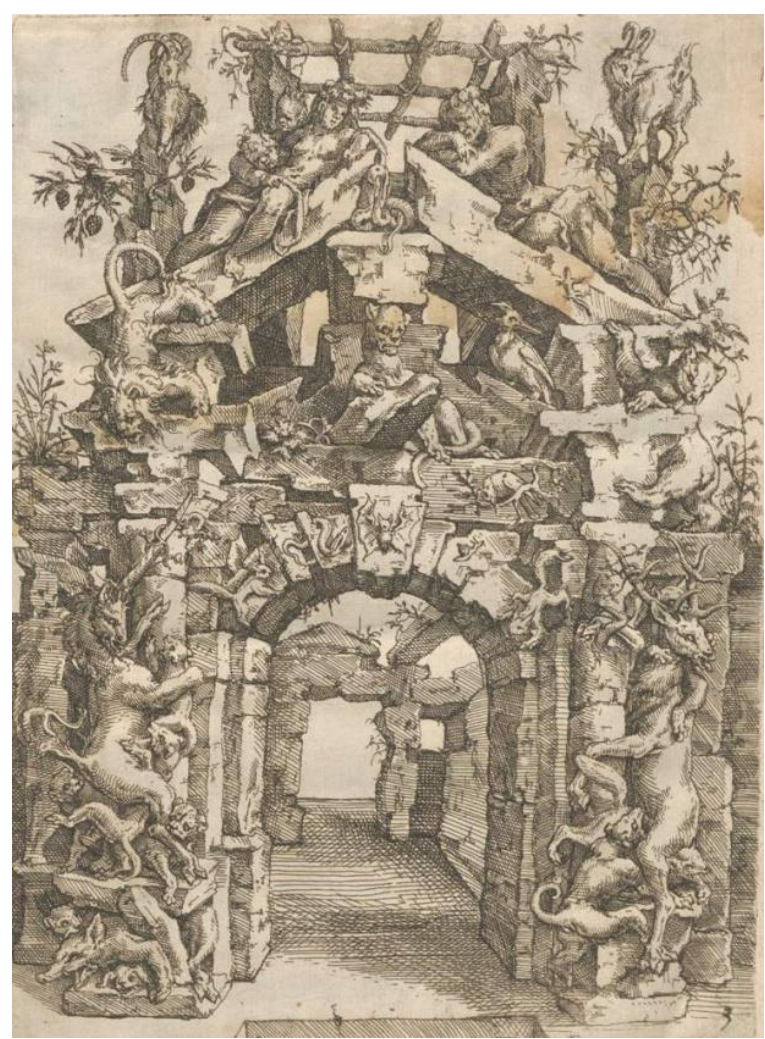

Figure 3. Dietterlin, Architectura, Engraving 24 


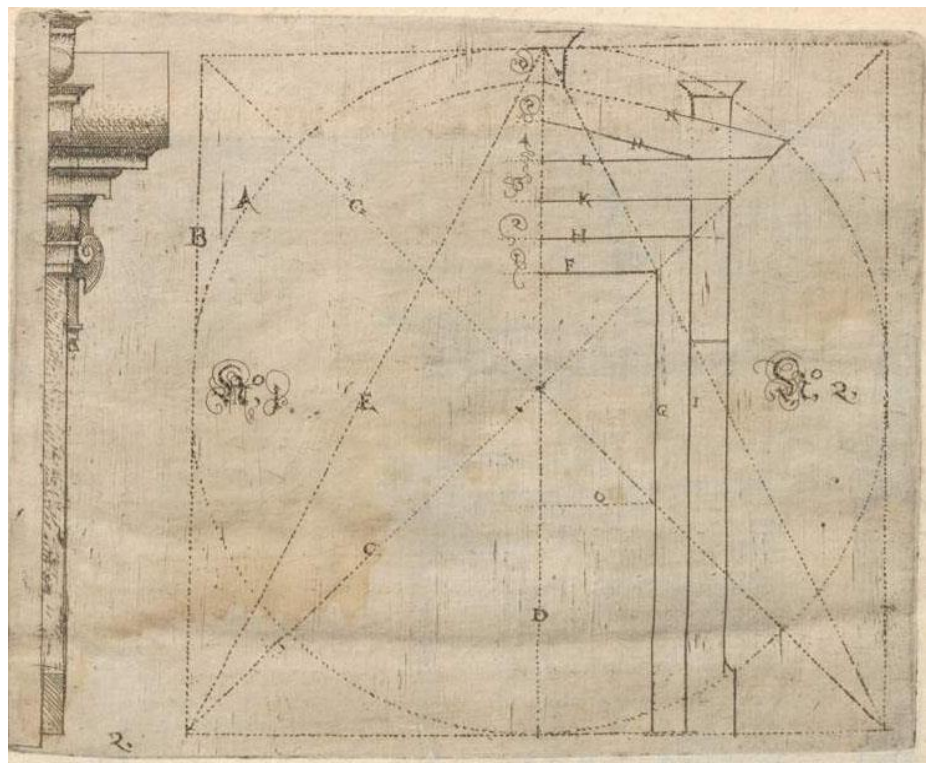

Figure 4. Dietterlin, Architectura, Engraving 23

It seems that this idea continually develops trough the examples of fountains and pools related to the Tuscan Order. Besides the engraving 35, repeating the characteristics of compositions with the Bacchus figure accompanied with motives as Pan, goat, and vine (Figure 5), Dietterlin presents a few other narratives more complex in their cultural meanings.

The engraving 32 depicts culmination of a dragon slayer story, obviously as an unavoidable reference to the primordial character of the Order (Figure 6). There are two possibilities related to the source of the motive. The first one, that it is the representation of the fight of the Greek hero Cadmus, the mythological founder of Thebes. ${ }^{20}$ However, there are a few important elements indicating the possibility that depiction could be related to the Nordic - German story of Siegfrid the dragon slayer. Dragon has the bat - like wings without the snake like body, which is opposite to all ancient Greco - Roman sources related to the story. More than that, the hero brandish with a sword for the final blow, which is an important detail in the story of Siegfrid's fight. He kills the dragon with his sword named 'Balmung' (Nordic 'Gram'), containing almost magical powers and strength. Nevertheless, belonging to the first or second tradition, the narrative is important as a representation of an essential fight between good and evil. However, it is not a military motive but a reflection on the struggle between cultivation and chaos, which belongs to the primordial times and the earliest history of shaping human society, culture, and believes, and by that inexorably linked to the Tuscan Order. To the dramatic atmosphere of the dragon slayer composition correlates the engraving 36, where a hunting scene is presented. In the middle of the pool around a Tuscan column a crowd of figures of hunting dogs is placed, and a hunter stubbing a bear with a spear in a strong movement. 468.

20. Adamska, Wendel Dietterlin Starszy: Jego Architectura von Austheilung Z. R. 1598, 2003, 


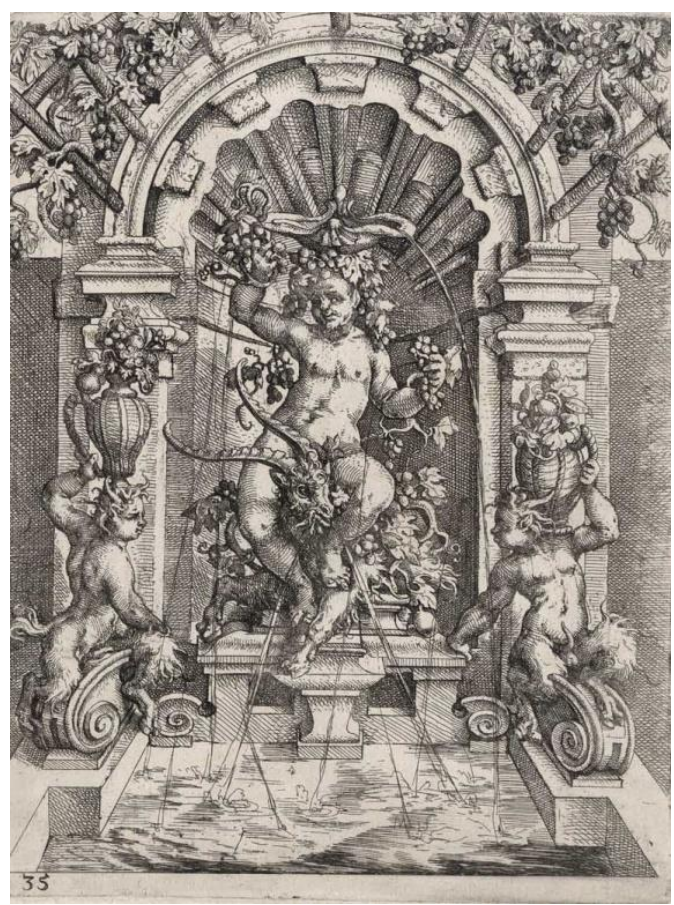

Figure 5. Dietterlin, Architectura, Engraving 35, 1598

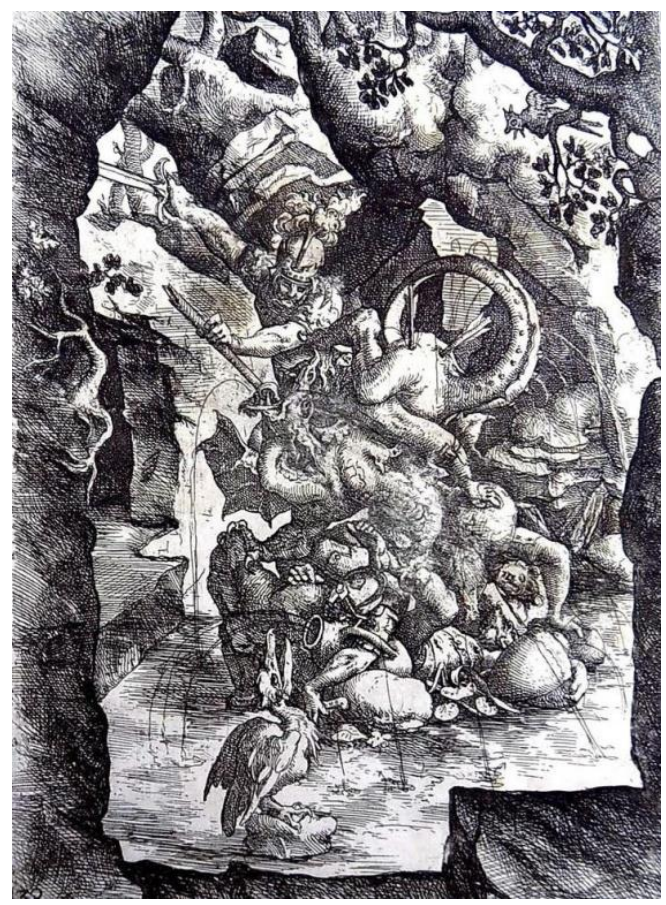

Figure 6. Dietterlin, Architectura, Engraving 32, 1598

Opposite to these violent scenes, the engraving 34 is composed in a completely different temper. A serene feeling of basic and important everyday routine on which the beauty of simple life is established, emerge from the composition 34. A young man pumping water from a fountain composed as a highly sophisticated piece of architecture, and a girl carrying water from the well, 
are presented as the centre of the narrative. Fountain is placed on the tri-partite geometrically shaped water collectors. This perfectly formed and by time unspoiled architectural object is placed within a ruin, probably as a part of Dietterlin's metaphorical narrative. We can guess about the real meaning of the presentation, but it seems that it carries a few fundamental thoughts probably related to the inviolable notion of fons vita, and the family life as the essence of human existence. While everything around it decays, the real well of life remains unspoiled.

\section{Doric Order}

Contrary to his personal metaphorical interpretation of the Tuscan Order, Dietterlin at the first place, follows in a precise way the Vitruvian and Renaissance tradition regarding the Doric Order's meaning established mainly as the male warrior character. $^{21}$ This is evident from his engravings 46 and 73 , presenting a male warrior figure equipped and surrounded with various pieces of arms (Figure 7 and 8). However, this dominant metaphor has been supplemented with other corresponding meanings presented through narratives belonging to ancient mythological, Biblical, and contemporary tradition. They broad our understanding of strength, war, the notion of fight and struggle in general, as the human personal and social activity.

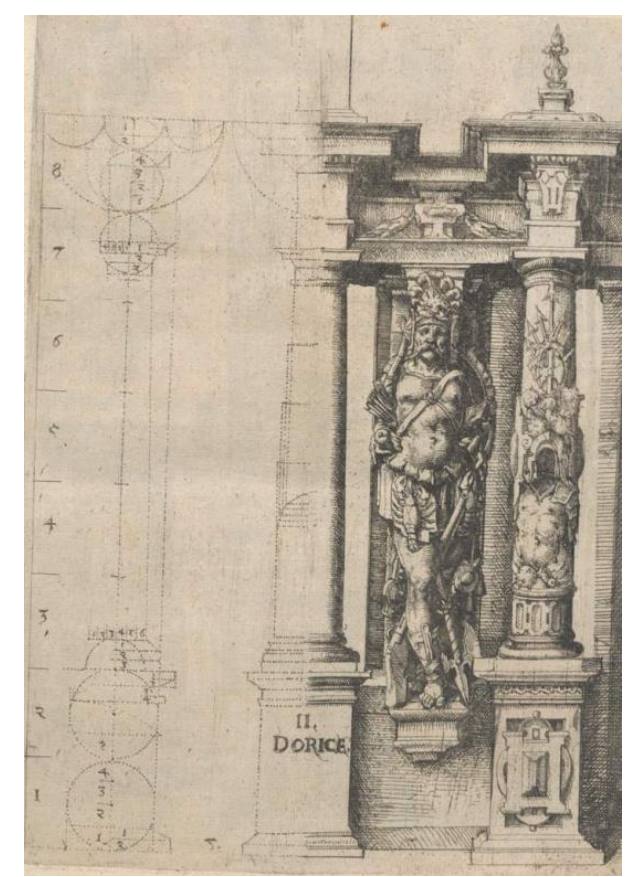

Figure 7. Dietterlin, Architectura, Engraving 46, 1598

21. Skelton, "Shaping the Book and the Building: Text and Image in Dietterlin's 'Architectura,"' 2007, 27; Forssman, Saule und Ornament: Studien zum problem des Manierismus in den Nordischen Saulenbuchern und Vorlageblattern des 16. und 17. Jahrhunderts, 1956, 163. 


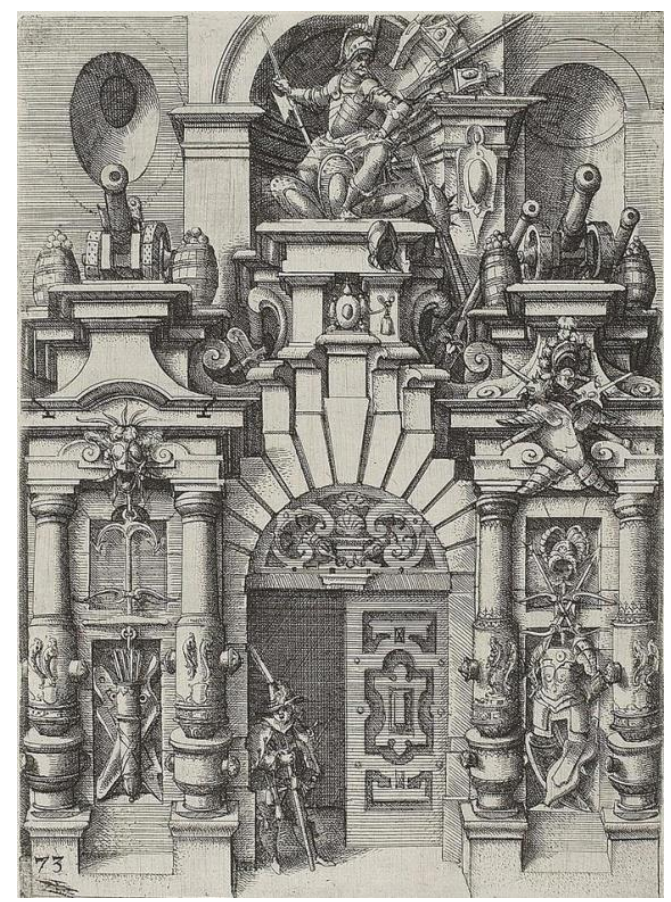

Figure 8. Dietterlin, Architectura, Engraving 73, 1598

Following the engraving 73 representing a portal with the male warrior character, a fully armed soldier on the top of the entablature, the composition 74 depicts the principle of its female counterpart, one of the ancient warrior goddess Diana. Being also the hunting goddess, Diana carrying a spear, is surrounded with a number of dogs. Portal is decorated with heads of a deer, bear, and boar. On the right side of the portal a bear is presented carrying a broken spear. This engraving seems to be in a direct correspondence with the next one in the line (engraving 75), representing a portal of a tavern, decorated with a hunting catch, boar heads and sausage. Two male characters are presented. In a lower zone a column like figure of an innkeeper, and up the entablature a young male with a horn of plenty. It seems that the presented motive reflects on Dietterlin's personal artistic approach to interpretation of characteristics of architectural orders through free associations - here probably as the benefit of hunting through the idea of plenty.

One of the purest ancient mythological motives we can find in engraving 77, where in the upper zone a figure of Jupiter is presented seated on an eagle, and carrying aegis and scepter in his hands. Personifications of Sol seated on a bull on the left, and Luna seated on a lion on the right side are accompanying the god, confirming that Jupiter's appearance is a cosmic event. Eagle as symbol of heavenly sphere, bull as symbol of natural forces, and lion as symbol of earthly power, are completing the idea of Jupiter as the supreme authority in spiritual and material universe, and the leading warrior against chaos. He represents a sublime male power in its essence, and according to Dietterlin, it seems that by this characteristic such representation belongs to the Doric Order (Figure 9). 


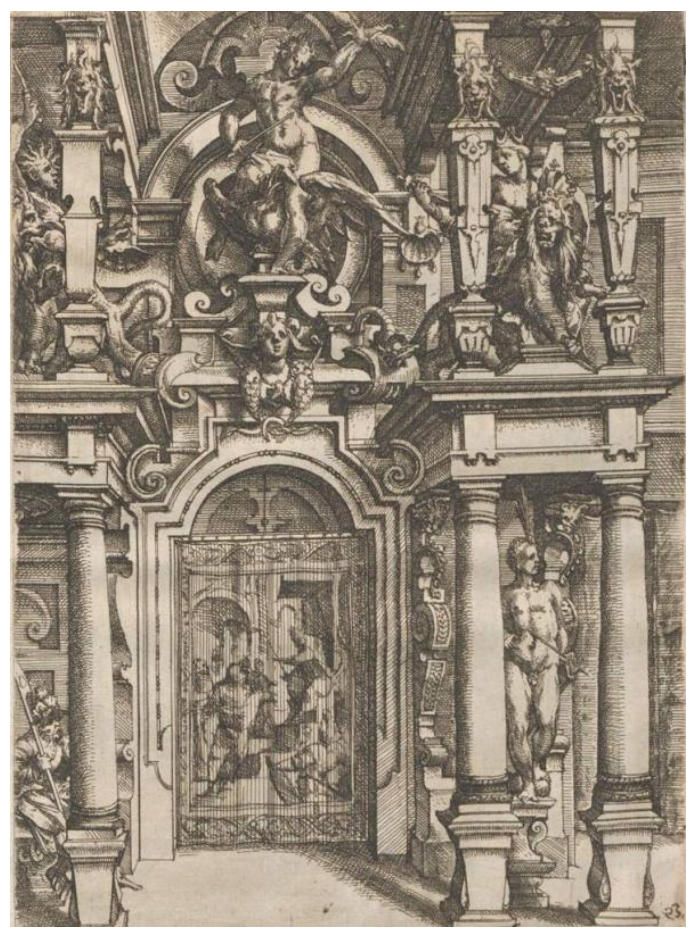

Figure 9. Dietterlin, Architectura, Engraving 77, 1598

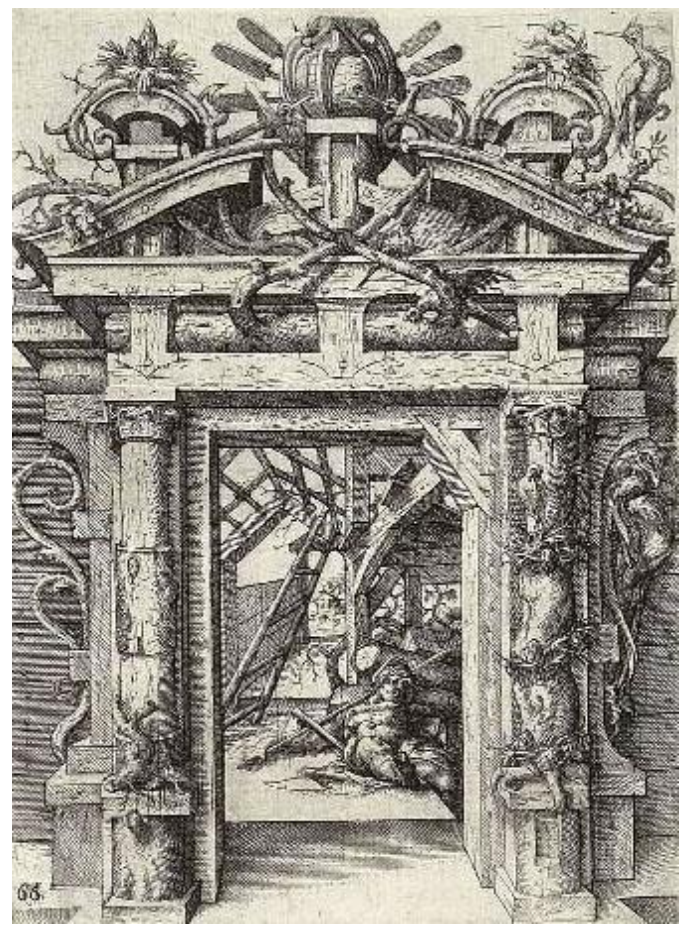

Figure 10. Dietterlin, Architectura, Engraving 66, 1598

To his collection of portals shaped through various interpretations of characteristics of the Doric Order, Dietterlin attached two examples containing historical connotations. In engraving 76 , he presented an exceptionally decorated portal with the bust of Caesar over the entrance, probably referring to the dictator 
as the personification of supreme warrior in ancient history. The second engraving (no.66) illustrates the generally accepted opinion, developed by the Vitruvian and Renaissance tradition, according to which the Doric Order originates from primordial wooden structure. However, Dietterlin subordinated the characteristics of the portal's form to his vision of general proportional and compositional values, presented at the beginning of the book in the engraving 23. Except the pair of columns flanking the entrance, and presented almost as untilled trunks, the other structural parts of the portal are executed and assembled with high precision (Figure 10). Actually, Dietterlin designed a sixteenth century mannerist portal made of wood. A counterpart of this structure is presented in engraving 52, as a wooden window with almost the same characteristics, and together with the first example testifies for Dietterlin's ambition to interpret all important aspects concerning the Order.

His reflection on various religious and cultural notions connected to generally assumed characteristics of the Doric Order, Dietterlin continues to develop in design of fountains and pools. Composition presented in the engraving 78, is identified as the scene from the book of Genesis, where angel presents itself to Hagar and Ismail on their trip to Egypt. ${ }^{22}$ Not entering into the theological particularities of the story, we should emphasize that in the Christian tradition it was usually interpreted as a metaphor of struggling for redemption and against oppression. ${ }^{23}$ In that context, the righteous fight for the purification of a soul seems to be for Dietterlin a sufficient point for associating it with the strength of the Doric Order (Figure 11). Probably from the similar reasons the depiction in engraving 79, took the place within the collection of various Doric characteristics. Composition presents a splendid design of a well with a figural composition on its top: the figure of Christ blessing two jars carried by servants. It seems to be a Christian counterpart of the previous story from the Old Testimony, presenting the moment of the first Christ's miracle performed at Cana in Galilee: transformation of water into wine. From that moment new faith began to fight for the redemption of peoples' souls, and the recognition as truthful religion.

One more important Christian theme has been presented in the engraving 82 , where the cross like fountain carries a complex figural composition. In the centre of the fountain a dominant figure of St. Christopher is positioned carrying the divine child, taking a step over a water creature (Figure 12). Over their heads a globe with the cross on the top is placed, identifying the child Christ as the redeemer of the universe. However, this basic iconographic motive Dietterlin supplemented with four grotesques like water demon creatures wearing various objects allegorically identified with sins of egotism and immoderate earthly pleasures, by which they try to tempt the holly couple. We should emphasize that such compositional additions to St. Christopher's iconography are not unusual in the European sixteenth century art, particularly in artistic circle under the influence of Hieronymus Bosh. We can refer, for instance, to the painting of Jan Mandijn, from the middle of the sixteenth century, now in the State Hermitage in St.

22. Adamska, Wendel Dietterlin Starszy: Jego Architectura von Austheilung Z. R. 1598, 2003, 477.

23. St. Augustine, The City of God, $2^{\text {nd }}$ volume (Edinburgh: John Grant, 1909), 41-42. 
Petersburg, where similar fantastic context of the subject is presented. It seems that Dietterlin as mannerist painter accepted such a phantasmagoric approach, emphasizing the essence of the theme, crossing over the water of sin, and struggle for spiritual virtue through the Christian fate.

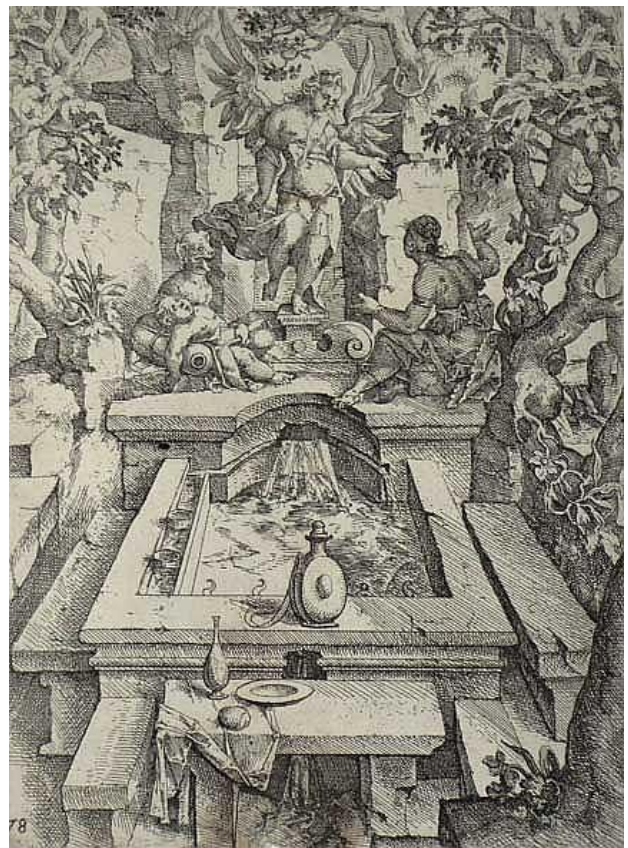

Figure 11. Dietterlin, Architectura, Engraving 78, 1598

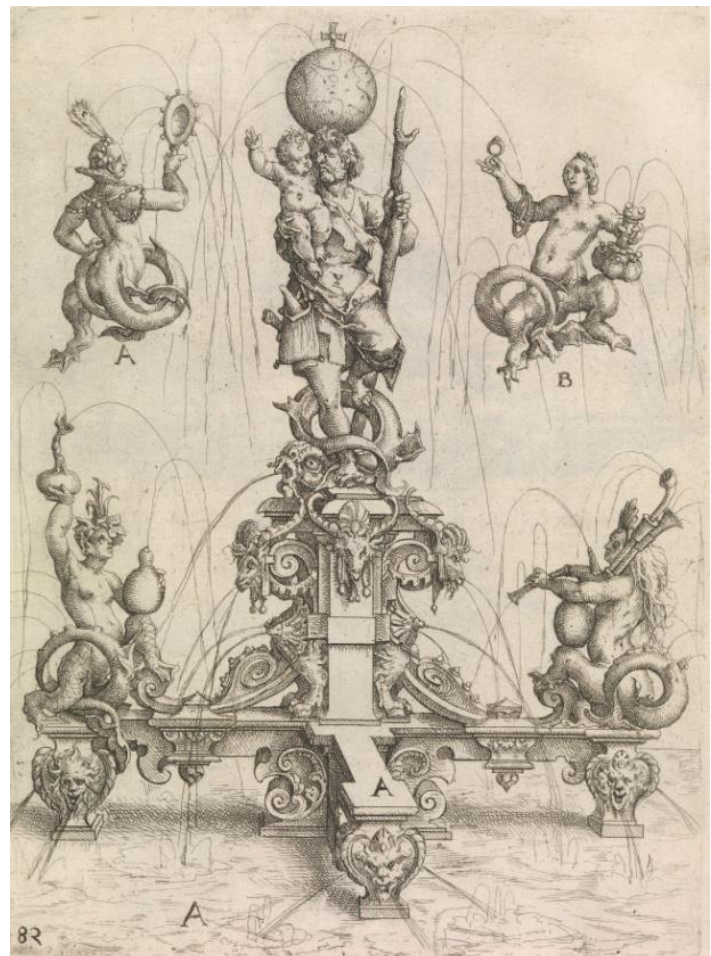

Figure 12. Dietterlin, Architectura, Engraving 82, 1598 


\section{Ionic Order}

After presenting a number of various subjects exposing the nature of power and force of arms, but also themes of spiritual struggle, as dominant characteristics related to the Doric masculine sensibility, Dietterlin develops a different kind of sensitivity affiliated to what Vitruvian and Renaissance tradition generally named as feminine character of the Ionic Order.

In his engravings, it seems that Dietterlin points out two conceptual approaches in defining metaphors linked to this Order. The first one is particularly attributed to the nature of variable feminine characters as possible representatives of the Ionic Order, while the second group contains examples through which we can experience the general sensibility regarding the Order itself as a generator of cultural ideas. In this context, attained complexity of metaphorical narrative intensified by Dietterlin's method of side by side presentation of ancient, Christian and contemporary motifs.

To analyze this approach we should pay particular attention on two compositions, one presenting characters from ancient Greek mythology, and the other based on the story from Christian tradition. In engraving 105, a monumental female figure is presented standing on a pedestal carrying inscription Libertas. It seems that the female personification of Freedom, as a notion added to the Ionic Order, refers in a way to the logic of succession of five Orders in Vitruvian and Renaissance architectural tradition. After examples illustrating various aspects of masculine sensibility for fight and struggle exposed within the Doric Order, the next one in line, the Ionic, spreads out a sense of relief, emphasizing the nature of feminine character through notions of freedom and peace. Such an orderly succession also seems to reflect on the change of seasons in nature, or the subsequent trace of events and their causality in human history.

Nevertheless, in the same engraving Dietterlin added to the composition a pair of embraced figures, a female and male, placing them in the left upper corner. By the bow in the female's hand and the boar's head with an arrow in its forehead, placed between the characters, they are identified as Atalanta and Meleager. ${ }^{24}$ According to the ancient mythology, Atalanta appears to be a victorious heroic character, free of passions as lust and envy. In a way, as an independent female character she achieved personal freedom, and by her capabilities was truly equal to all men and at the end to her husband Meleager. Probably that is the reason why the figure of Libertas points with her right hand towards Atalanta.

Emphasizing the female spiritual qualities, Dietterlin presents in engraving 117, the story of Christ and Samaritan woman. The well-known event occurred on Christ's way back to Galilee, where Photine (the luminous one), how the Samaritan women was named after her baptism, understood and recognized Christ as the Savior of the world, the bread and water of eternal life, becoming by that almost an apostolic figure in the Christian tradition. Using spiritually elevated female characters, Dietterlin seems to refer to the strength of eternal values of

24. Adamska, Wendel Dietterlin Starszy: Jego Architectura von Austheilung Z. R. 1598, 2003, 484. 
virtue, understanding and compassion as particular notions attached to the essential experience of the Ionic Order.

It seems that such Dietterlin's idea may be acknowledged through other engravings illustrating more general constitution of the Order's character. In the engraving 102 we can find a profound relationship between the character of the Ionic Order and the idea of peaceful times. Armor and arms are arranged as a decorative motive, accompanied by a figure of a putty holding palm and olive branches, as symbols of triumph and peace. More than that, there are engravings with motives of horns of plenty with figures of Bacchus like male characters. Dietterlin added scenes containing depiction of divine creative labor, as in engraving 109, where Hephaestus was presented accompanied by Venus and Amor (Figure 13). Moreover, in other compositions in equal manner are presented ancient divinities in elegant and tranquil atmosphere. Even in engravings depicting architecturally framed examples of warriors' monuments, they expose triumph rather than aggression.

In this context, engraving 123 is of a particular interest. A fountain is presented, designed as a perfect complex geometrical shape, with personifications of four German rivers, among which just one is named as Renus - Rhine. It is the one of the rare compositions in the book without any mythological or religious connotations, but emphasizing the natural wealth of Germany in a geographic notion. The rivers are presented as a source of plenty, and as a life giving power of the land (Figure 14).

However, despite the fact that all figures, female and male, presented in the book on the Ionic Order have been designed according to the tradition of classical elegance and sophisticated proportional system, one of them - first in the line, the statue column in the engraving 95, has been designed in the manner used for the column like male figure of the Tuscan Order. Composed out of different decorative and symbolical elements, this female figure leaves an impression as representing elementary earthly aspects combined with associations on a housewife role. Floral decorative elements instead of hair, symbolical image of a turtle on her skirt, household keys hanging from her belt, and unidentified wrinkle placed on the stomach, are making an impression of unsophisticated grotesque (Figure 15). 


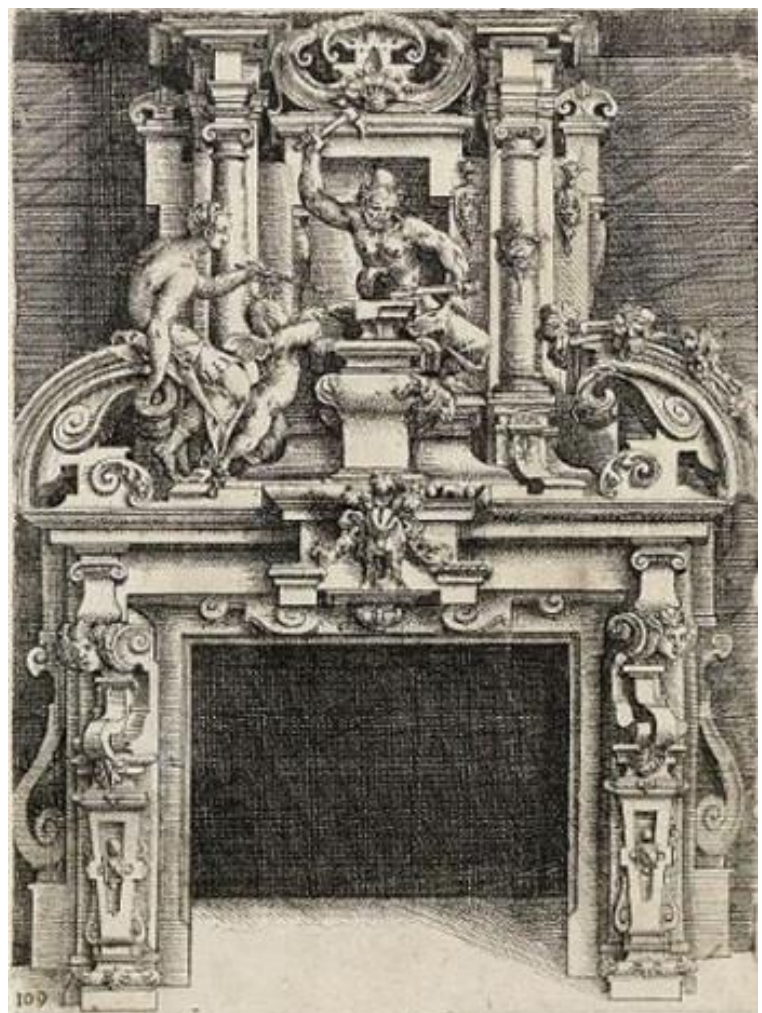

Figure 13. Dietterlin, Architectura, Engraving 109, 1598

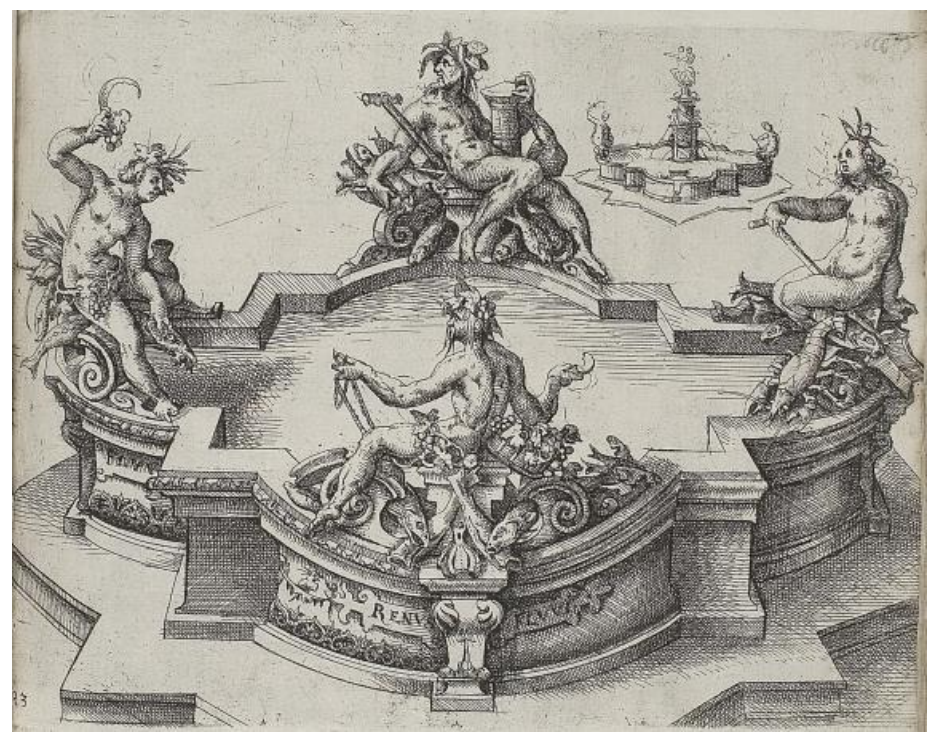

Figure 14. Dietterlin, Architectura, Engraving 123, 1598

\section{Corinthian Order}

Opposite to the female character from the introductory Ionic engraving, for the first presentation of the Corinthian Order, Dietterlin shaped a highly sophisticated image of a young girl according to the best classical artistic tradition 
(Figure 16). Besides, decorative elements added to the figure, the basket with acanthus plant placed over her head, are closely linked to the Vitruvian story of Callimachus' discovery of the Corinthian capital, presented in the Dietterlin's introductory text. Moreover, it seems that there is evidently a transformation of these elements into ornamental system applied to columns. ${ }^{25}$

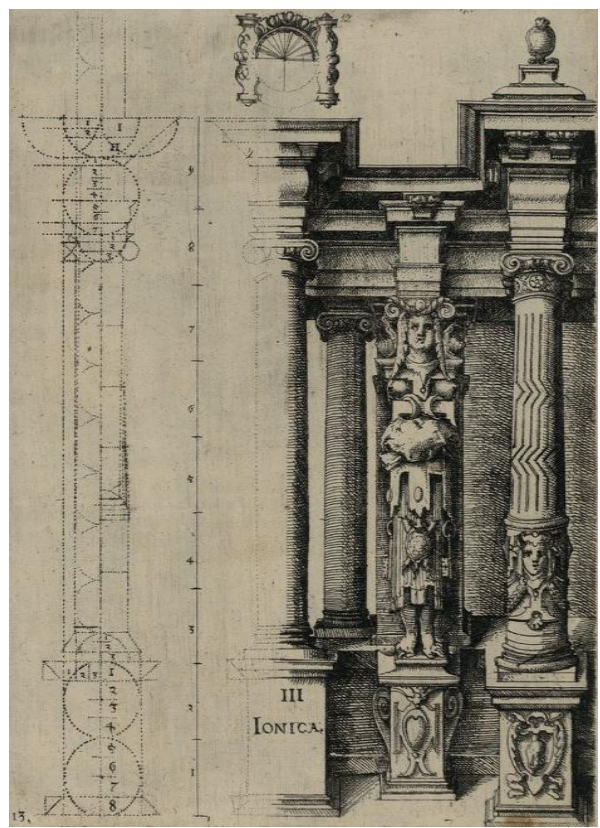

Figure 15. Dietterlin, Architectura, Engraving 95, 1598

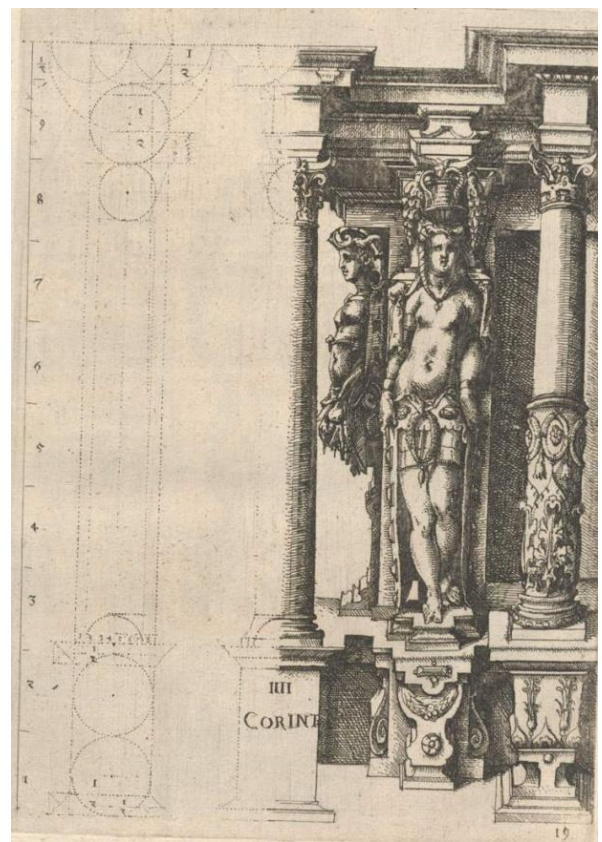

Figure 16. Dietterlin, Architectura, Engraving 136, 1598

25. Skelton, "Shaping the Book and the Building: Text and Image in Dietterlin's 'Architectura,", 2007, 33. 
It seems that Dietterlin through his choice of themes illustrating the Corinthian Order, developed various expressions related to the sense of sophisticated spiritual elevation as a general notion. In that context, the absence of motives as the horn of plenty and figures of Bacchus as metaphors of material wealth is particularly indicative. Also, instead of images of taverns, innkeepers, and hunt catch, to the perceiver is, for instance in the engraving 144, presented composition depicting a Christian moral critique of two mortal sins - envy and gluttony.

Personifications of envy, Invidia, and of gluttony, Gula, are chained to bases on which the figures presenting their retribution or righteous infliction are placed. At the left Invidia is lying, depicted as demonic old women devouring her own heart, accompanied by a wild animal, probably a bear. She is looking on an elegant female figure with a lamb at her feet, and cracking a heart, illustrating the act of retribution for the sin of envy. Placed on the right, personification of Gula eating, has been watched by a female character carrying a fork with just one radish and a glass with a small amount of liquid, probably water. The moralistic tone calling for the virtue of restraint is evident. Moreover, for his pictorial presentations of two sins, Dietterlin probably inclined to the customary sixteenth century iconographic model, broadly known and published at that time. ${ }^{26}$

Nevertheless, Dietterlin presented also more known and better understood biblical themes regarding the domination of spiritual strength and faith over earthly life and material world. In that context a simple composition of David carrying Goliath's head is depicted in the engraving 143, reminding the observer on the notion of being strong in God. The key moment in Christianity when Christ ascended to heaven, is shown in the engraving 146, as a picture incorporated within an architectural frame with a sculpture of personification of Church on the top.

However, in his further presentations of notions regarding spiritual elevation, Dietterlin also used themes arranged around ancient mythological characters and stories. One of them presented in the engraving 148, with Hercules as central figure, links the mythological story of his deeds and the virtue proclamed by the Christian faith. In his glorious appearance Hercules stands between two other figures symbolically prizing him, as it seems, with offers. At the left a young man orientaly dressed, in seducing arrogant pose offering the cup of vanity, and on the right side personification of Church in a humble and inviting pose of open arms carrying a cup with a cross inside. Turning his head towards the Church, Hercules acts in favour of eternal virtue of obediance and patience, as a sign of completenes of his spiritual strength (Figure 17).

Contrary to this composition addressing a simple spiritual message, the next two examples, are dealing with more complex ancient Greek mythological narratives. In the engraving 149, a known story is presented, that of Zeus and Io. The couple seated on an eagle is centrally placed in the upper section of the composition accompanied by putty. One of them is holding a lyre as the symbol of

26. A. Alciati, Omnia Andreae Alciati Emblemata cum Commentariis, quibus Emblematum Omnium Aparta Origine (Antverpiae: Ex Officina Christophori Plantini, Architypographi Regij, 1581), 171-173, 316-317. 
harmony, and the other one a rabbit as the symbol of fertility. In the lower zone, at the left the figure of Argus is depicted. He was primordial giant with hundred eyes, servant of Hera and the guard of Io. He was killed by Hermes which figure is placed at the right side of the composition, aiming towards the giant. These two characters are obviously presented to complete the narrative, which by its nature is not a lascivious one, as it can appear at the first glance, but based on the mythological notion of divine fertility and spreading of the new generation of more spiritually elevated beings.

Composition depicted in the engraving 150 seems to be engaged with the notion of the supremacy of the divine musical harmony, obviously based on the story of the competition between Apollo and Marsias. However, in comparison to the original mythological narrative, Dietterlin entered a few differences into his pictorial interpretation.

Figures of two rivals are placed in the lower part of the scene, Apollo on the right side with his lyre and the laurel wreath placed on his head, and Marcias with the Pan Flute on the left. As the judge in the competition, instead of muses, a female character is presented, which by the added attributes (the book, putty with a torch, and the crescent moon on her forehead) can be identified as the personification of Cognition. It is important to emphasize that this figure corresponds with the iconographic model, circulating in Europe at the end of the sixteenth and the beginning of the seventeenth century. ${ }^{27}$ As the larger iconographic difference to the usually accepted pictorial model of cognition is the appearance of an empty plate placed in her right hand. It seems that Dietterlin added this detail as a part of the communication between Cognition and Marsias, at the end of her verdict. Giving the advantage to Apollo as the god of harmony, she was presenting to Marsias his award, an empty plate as a cynical gesture of despising lowness and emptiness of his spirit.

Analyzed compositions, rich in narration, Dietterlin presented as integral parts of illustrated windows and fireplaces. In the collection of portals, he accepted a more moderated approach using figures mainly as personifications of highly esteemed cultural notions and relevant institutions of the society. Nevertheless, Dietterlin's affection with themes of spiritual purity and morally elevated ideas is not weakening. It takes just a variable form of expression, where figures are incorporated within particularly sophisticated architectural presentations which artistic characteristics are following the main metaphor in the composition.

27. C. Ripa, Iconologia overo Descrittione di Diverse Imagini Cauate dell'Antichita \& di Propria Invencione (Roma: Lepido Faci, 1603), 71. 


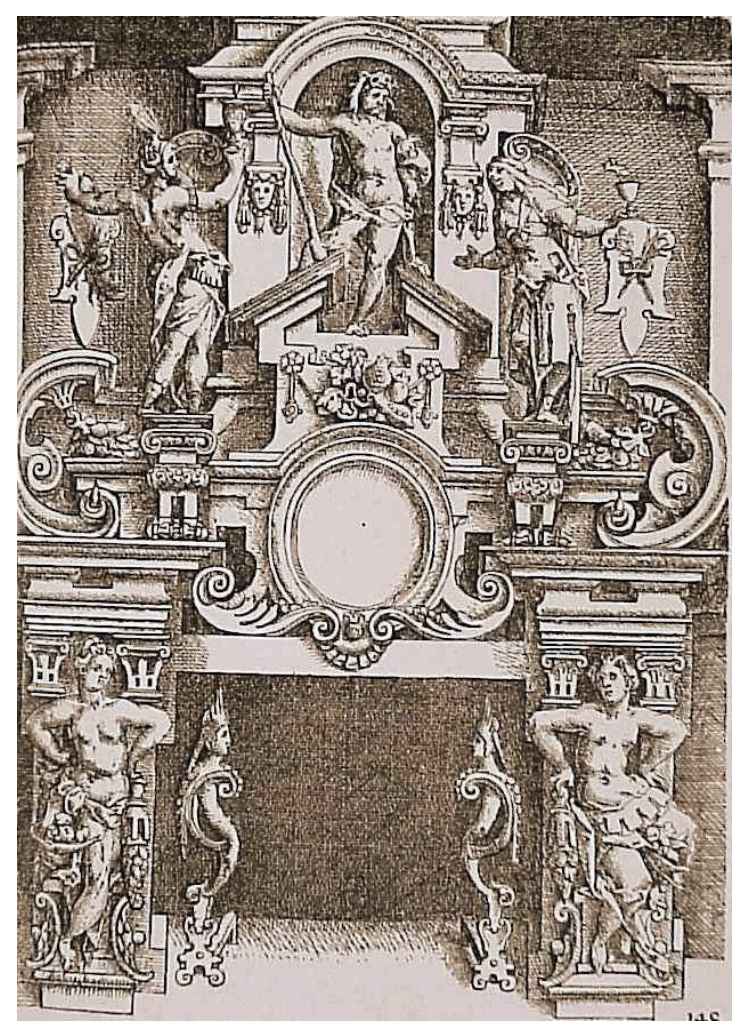

Figure 17. Dietterlin, Architectura, Engraving 148, 1598

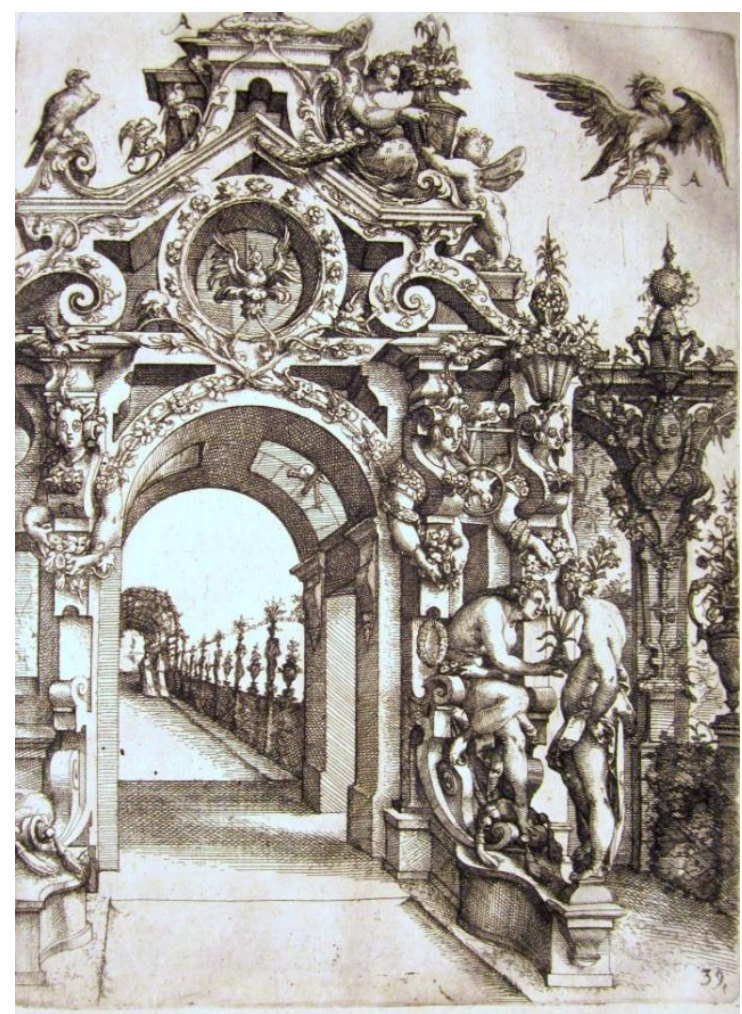

Figure 18. Dietterlin, Architectura, Engraving 152, 1598 
The first of those examples Dietterlin presented in the engraving 152. Architecture of the gate, which opens a view down a garden path, is richly decorated with grotesque like female busts composed with additional floral elements. Moreover, floral motives are also added to the surface of the building's elements, and it seems that they are used as constitutive metaphorical meaning of the whole composition. On the right side of the gate two figures are placed. A sitting young male is presented as exchanging a lily flower with a standing female figure. The exact meaning of this act is uncertain, but keeping in mind that the lily flower symbolizes the virtue of purity, it seems to be related to a presentation of maidenhood without any approval for passing the gate can't be gained (Figure 18).

Two more symbols are incorporated into the presentation, and it seems that they are essentially correlated with the general metaphorical meaning of the scene. In the oculus positioned immediately over the gate arch, figure of phoenix is placed, as a symbol of spiritual rebirth within the eternal circle of life, and from the top of the whole composition dominates a figure of an eagle presenting the supreme divine heavenly power. Sentimental feeling developed through analyzed elements suggests the metaphorical depiction of the garden of eternal life, maybe related to the introductory story of the Corinthian maiden.

The metaphorical meanings of the next two examples are more certain and understandable.

A portal designed in a strict manner with plane columns and even surfaces, is presented in the engraving 157. By these characteristics architecture supports the notion of gravity that the institution of Justice should have. The figure of personified Justice is placed on the top of the architectural composition, carrying in her hands a sword and a weight. To her dominant and almost holy appearance two female figures are complementing. At the right side of the personification of Justice, Dietterlin placed a figure of young women holding the tablets of Ten Commandments and a torch, while at the left side the other one is attributed with a victorious wreath and a palm branch as insignia of triumph (Figure 19).

The engraving 160 contains the second example we will pay attention to. It is a presentation of architecturally balanced composition, almost classical in its expression. To its sophisticated design contributes the absence of exaggerated decoration visible in the majority of Dietterlin's engravings. One can sense the harmoniously restrained notion of the architectural form, which embraced just a few figures. The most important of them, placed in the upper part of the gate, are five maidens, a company of musicians performing for the goddess Athena. The scene brings up her attributes as goddess of cultivation and ascent of reason, as prerequisites for a harmonious human society. In that context, the figure of Pegasus, the ancient symbol of spiritual elevation, placed on the top of the architectural composition, completes the notion of this profound metaphor.

The last example we will discuss within the line of engravings characterizing the Corinthian Order, is also compositionally the most complex one. It presents a fountain assembled from four parts, each of them personifying one of the elements of the material world we are living in. The engraving 162 presents the element of 
fire; the element of air in the engraving 163; of water in 164 , and earth in $165 .^{28}$ They are all arranged together around the pool in the engraving 166, by placing the personification of water in the middle, with the fire above it. On the left side from the central part, the personification of earth is placed, and on the right of air. All together, they form a complex metaphor presenting the entire material nature of the universe (Figure 20). It seems that this way Dietterlin emphasized the entirety of material principles of natural laws, as fundament of permanency between divine and human manifestations of elevated spiritual values. By this, he characterized the Corinthian Order as a supreme expression of sophisticated dualistic completeness of the material and spiritual world.

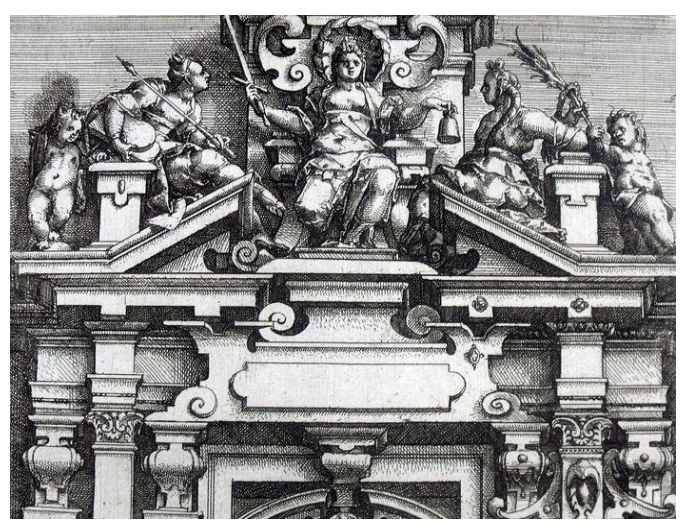

Figure 19. Dietterlin, Architectura, Engraving 157, 1598

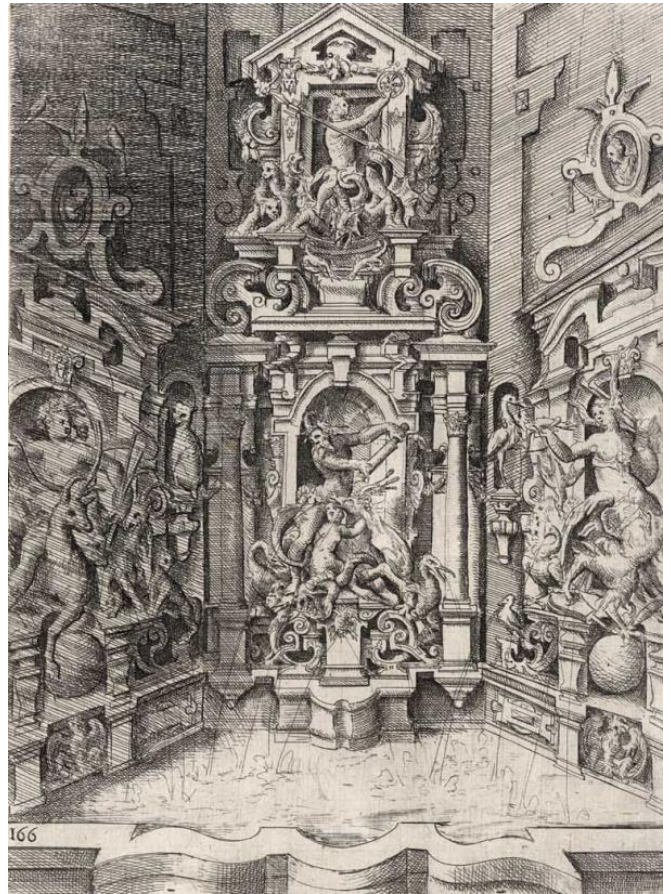

Figure 20. Dietterlin, Architectura, Engraving 166, 1598

28. Adamska, "The Tuscan/Rustic Order: A Study in the Metaphorical Language of Architecture," 2003, 498, 499. 


\section{Composite Order}

In comparison to the first four books, the fifth, illustrating the characteristics of the Composite Order, contains the smallest number of engravings. Moreover, to his selection of themes Dietterlin did not include any mythological narrative belonging to the ancient Greek and Roman tradition. It seems that his idea, presented in the small introduction text, that the Composite Order is "more pure and subtle than Corinthian", developed through his pictorial interpretations in a particular way. ${ }^{29}$ Dealing with ideas of triumphant spiritual and moral powers as universal human and social values in his fourth book, in the next one Dietterlin continuously developed an image related to the supremacy of the Christian universe and its essential teachings. However, it seems that according to this task he developed approach related to various particularities of that universe and their representations.

In the context of Dietterlin's statement regarding purity and subtlety of the Composite Order, the characteristics of the column like female image represented in the introductory engraving 176 looks almost confusing. It is composed in the same manner and by similar means as the introduction figures of the Tuscan and Ionic Orders. These three representations seem to create a coherent ideological motive, and if we may say, almost a German principle of a new artistic invention (Figure 21).

Nevertheless, in the engraving 187-188, Dietterlin presented the idea of gradation of the five Orders, as a pure architectural sensation related to their visual characteristics and perceptual qualities. The first plan of the engraving is occupied with shaded representation of three Greek Orders, Doric, Ionic, and Corinthian, placed one upon the other. It is an accurate depiction of their ancient features, without any Renaissance or Mannerist supplements. However, by presenting the five Renaissance Orders through a shiny grandiose architectural structure just behind this shaded image, Dietterlin was contrasting the architectural characters of these two groups of orders. At the same time he emphasized their generative connection. In that context, the second architectural structure consisting on five Renaissance Orders, appears to be a complex one, particularly by the manner how Dietterlin interconnected their characters.

The oldest one, strongest and most rustic Tuscan Order took the ground floor. More elegant but still strong in appearance, the Doric Order occupies the position of the first floor. By using Ionic elements the second floor is structured and supplemented with a classical caryatid on the corner. With elements of the Corinthian Order the third floor is shaped, extending to a terrace with an obelisk on the corner finishing an elegant balustrade. Unusually presented, the idea of Composite Order is suggested through the appearance of one single column placed on the corner of the roof terrace.

However, our perception of this usual successive structural arrangement of five Orders has been manipulated by Dietterlin in a particular way. From the

29. Dietterlin, Architectura von Ausstheilung/Symetria und Proportion der Funf Seulen/und aller darauss volgender Kunst Arbeit von Fenstern/Caminen/Thurgerichten/Portalen/Bronen und Epitaphien, 1598, 176. 
ground floor to the top, every following floor differentiates not only by proportions inherent to each Order. Their heights are subordinated to the successive reduction, forming a perspective sensation in a way that it attained visual lightness of the upper floors. This effect offers an impression where the elegant architectural structure of the fourth and fifth floor visually merges with the sky. Accordingly, Corinthian and Composite Orders are not only visually most pure and subtle, but they also through use of metaphorical language offer the possibility in expressing the most elevated and sophisticated spiritual ideas.

Moreover, in this context one can assume that the Composite Order offers more possibilities than other four to be the carrier of new architectural inventions. One of these mannerist inventions, as already stated by other researchers, relates to the Dietterlin's idea that the Composite Order by its potential can be intertwined with Gothic elements. ${ }^{30}$ However, in this context one should be more precise when defining the possible Gothic elements used in Dietterlin's arrangements.

As shown in the engravings 197 and 203, we can perceive use of a system based on arrangement of different architectural elements in multiple layers. Actually, it proves the approach of overlapping as the essence of mannerist invention, and according to this, the value of intuitional perception shading the rational architectural structuralism. ${ }^{31}$ These kind of achieved perceptional values are supporting appearance of different intuitionally invented architectural characters as new cultural artistic expressions (Figure 22).

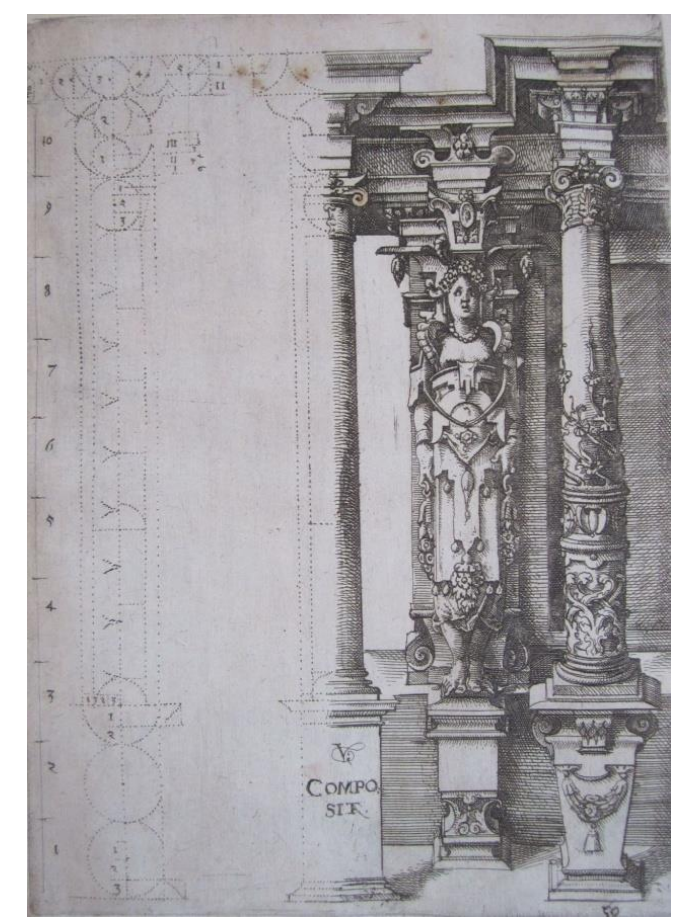

Figure 21. Dietterlin, Architectura, Engraving 176, 1598

30. Skelton, "Shaping the Book and the Building: Text and Image in Dietterlin's 'Architectura,", 2007, 37.

31. Forssman, Saule und Ornament: Studien zum Problem des Manierismus in den Nordischen Saulenbuchern und Vorlageblattern des 16. und 17. Jahrhunderts, 1956, 30. 


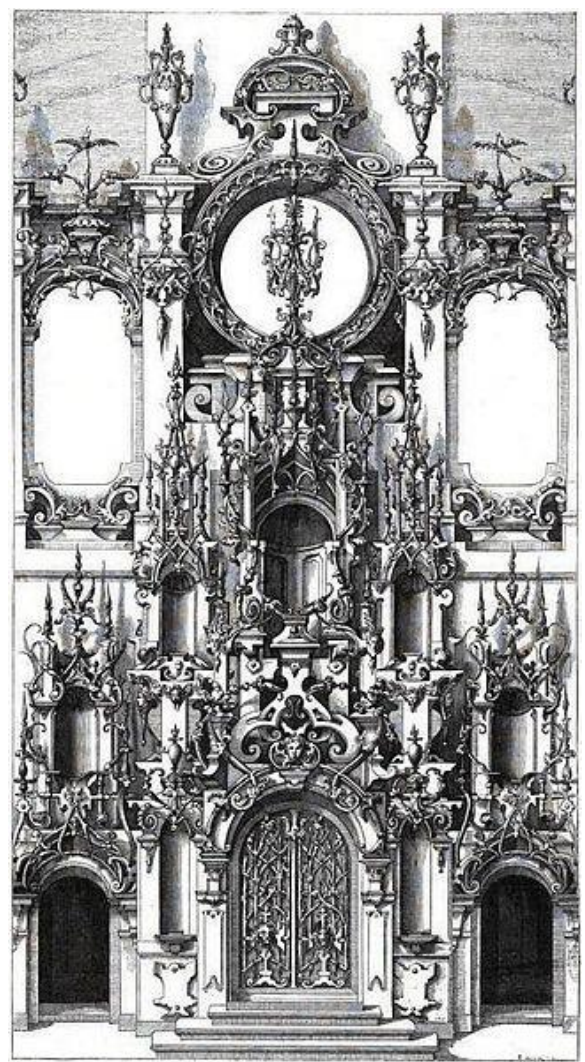

Figure 22. Dietterlin, Architecture, Engraving 197, 1598

In the examples in focus, the primal architectural composition is based on the mannerist sense of monumentality. Over it, as the second layer, appears a woven lace like decorative system, which is not integrated structurally with the primal wall, but just visually supplemented to it. However, the architectural characteristics of this second layer seem to follow the spirit of the Gothic architecture, but at the end they are not formed according to a pure Gothic expression. Rather it is a hybrid form of decoration incorporating elements of the sixteenth century art of Grotesque which in a linear way imitates Gothic shapes.

Nevertheless, Dietterlin used elements of, at that time, popular art of Grotesque in his book abundantly, and in that context such hybrid decorative forms have not been far from his artistic sensibility. It should be noted that one of the architects, Vredeman de Vries, whose influence on Dietterlin has been already recognized through his metaphorical approach to architectural design, ${ }^{32}$ also published a book on the art of Grotesque. ${ }^{33}$ Actually, it seems that his ideas also extended on the Dietterlin's use of grotesque as a form of creative expression. However, in analyzed examples these forms, as it seems, are profoundly and systematically arranged in a search for invention of a new German architecture,

32. Adamska, "The Tuscan/Rustic Order: A Study in the Metaphorical Language of Architecture," 2003, 449.

33. H. Vredeman de Vries, Grottesco in diversche Manieren (Antwerp: Gerard de Jode, 1560). 
but as an element incorporated in a complex expression of the sixteenth century culture. $^{34}$

The second important theme related to the presentation of universal values as expressive characteristics of the Composite Order, develops through narratives capital for the Christian faith and the Church. The engravings 203, 205, and 206 are presenting compositions of coronation of the Mother of God, adoration of magi, presentation of the instruments of martyrdom to Christ, the victory of St. Michel over the devil, and the Mother of God with the Christ child in glory. These compositions released from any extreme passion correlate with the idea of sophisticated spiritual elevation, as the essential character of the Composite Order (Figure 23).

However, there is one exception in this context. The engravings 199 and 200 offer a glorious design of a fountain which sculptural composition presents the martyrdom of St. Sebastian. He was universally popular saint at that time in Europe, as the protector from plague, and because his two martyrdoms have been a model of persistence in faith. Actually, this was the most excellent theme of the sixteenth century, and by that unavoidable in Dietterlin's collection of Christian narratives.

The engraving 201 depicts a fountain on four corners carrying figural interpretations of world's continents: America, Africa, Asia, and Europe. This theme correlates in a broader sense with other two fountain designs already mentioned in our discussion, i.e. the personifications of four German rivers in the engraving 123, and of four material elements in illustration 166. Actually, these three examples are forming a separate topic in Dietterlin's book, revealing his permanent interest in presenting allegorical constituents of particular geographic areas, local and global, or material elements on which the nature consists. Such an artistic activity seems to be result of an intellectual impulse, and especially in the third example, for expressing new global human knowledge related to contemporary discoveries of the geographic and cultural wonders of the world. It offers a new sensation of completeness of the human existence, worldly and spiritually.

However, the last two engravings we will discuss are related to the notion of time: as nature's permanent cycle of seasons, but also as impermanency of the human earthly existence.

Placed within an architectural composition classical in its character, the personification of summer seated on a lion, represents the central motive of the engraving $198 .{ }^{35}$ Under her feet a seasonal clock is depicted with the personifications of spring and autumn. On the top of the composition a huge clock is carried by the personification of time. His figure is attributed with scythe and winged sand clock, metaphorically showing the power of time over the mortal beings.

34. Kurt, "Den Maler, Wendel Dietterlin," 1954, 24; Forssman, Saule und Ornament: Studien zum Problem des Manierismus in den Nordischen Saulenbuchern und Vorlageblattern des 16. und 17. Jahrhunderts, 1956, 167.

35. Adamska, "The Tuscan/Rustic Order: A Study in the Metaphorical Language of Architecture," 2003, 507. 
This somber indication of human temporality is fully expressed in the engraving 209, as the last Dietterlin's metaphorical message to his readers. Universality of death as human's unavoidable end, has been presented by a crypt 'decorated' with figures of an old man and women, a skeleton, candles, arms and armors hanging on the wall. Over this arrangement presides a pair of huge wings, sand clock and two trumpets, probably as announcing instruments of the Judgment Day. Two saints seated in the front of the crypt, Moses on the right and Hieronymus on the left side, are reminding the observer on the final stage of the earthly life (Figure 24).

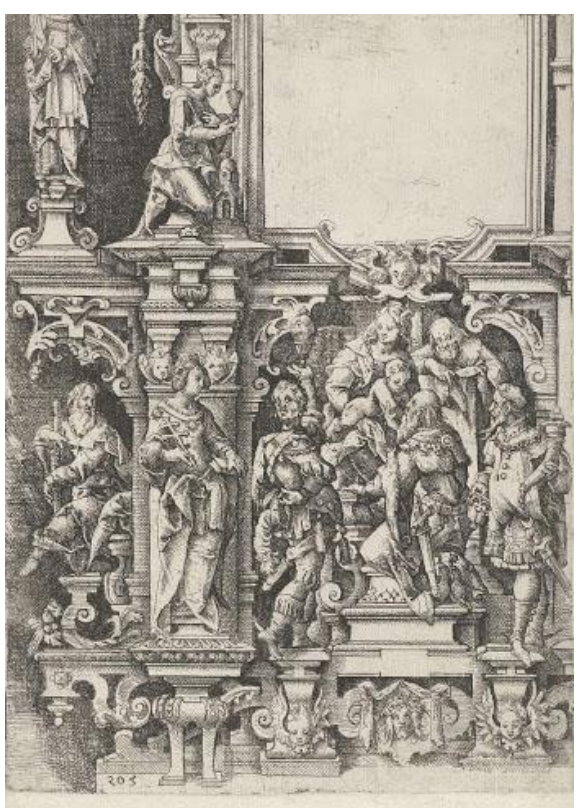

Figure 23. Dietterlin, Architectura, Engraving 205, 1598

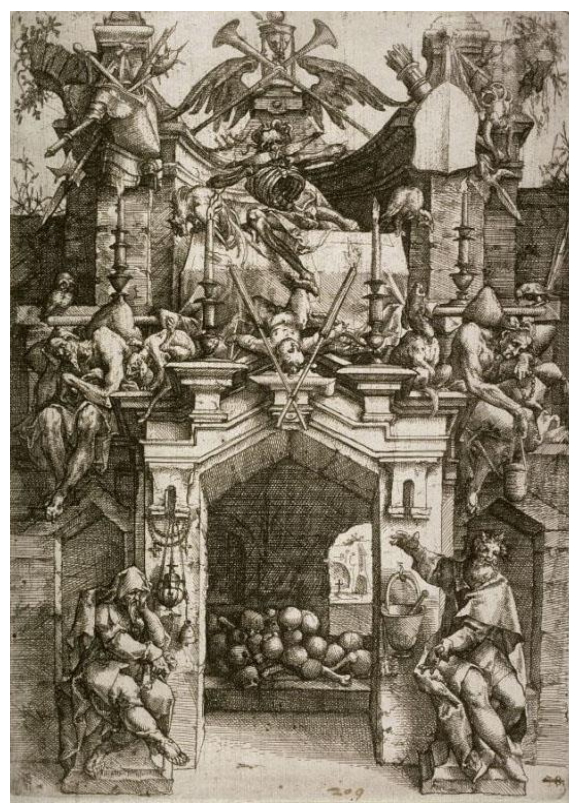

Figura 24. Dietterlin, Architectura, Engraving 209, 1598 


\section{Conclusions}

Our discussion on Dietterlin's interpretation of characters of five architectural Orders originated from the Vitruvian and Renaissance tradition, emphasize not only the individual Mannerist approach, but also a complex engagement with the sixteenth century German cultural and social aspects relevant for the issue in focus. Moreover, architectural Orders have been interpreted as integrative factor of ancient and contemporary culture of the time, resulting in a process of experimenting with new architectural inventions. Actually, Dietterlin developed a creative pictorial language as a kind of complex historical and cultural narrative, including general reflections on permanent human spiritual elevation. Without entering his narratives in detail, followed by the process of comparison of each character given to the five Orders, the general idea of Dietterlin's book would remain in the field of obscure interpretation. That is probably the reason why some architectural historians expressed a level of reservation regarding the permanency in Dietterlin's intention to define the "spirit of the Orders." 36

Particular value of Dietterlin's approach to cultural merging of ancient and contemporary elements refers to his attitude that Classical architecture can be thought as universal cultural achievement, a base on which one can imprint almost any artistic invention. This position is established on an understanding that the Classical proportional system appears to be a universal artistic value, and that the contemporary sensibility should form its own variation of character applied to each architectural Order. This gave to Dietterlin a possibility to synthesize various cultural aspects and narratives, ancient and those developed in his own time, using the creative power of integrating architecture, sculpture, and pictorial expression. By this, he proves decoration to be a metaphorical cultural system of his time.

Nevertheless, the book is composed by using an intriguing mixture of various mythological traditions, which often gives to the acting personalities and their characters ambivalent narrative roles and meanings. However, we should emphasized that Dietterlin's imaginative representations also display well established knowledge regarding, for instance, ideas of primordial character of materialization and structuring through which some Orders appeared in the first place. We should emphasize that by all indicated qualities, Dietterlin's book remains a unique work not only in the sixteenth century Germany. The seventeenth century in Germany can be named as period when Mannerism flourished in the full cultural capacity. There is indication that Dietterlin's book played an important role in the process of forming its cultural language. However, the possible influence of this work on the future development on architectural and artistic ideas should be further analyzed.

\section{Bibliography}

Ackerman, J. "The Tuscan/Rustic Order: A Study in the Metaphorical Language of Architecture." Journal of the Society of Architectural Historians 42, no. 1 (1983): 15-34.

36. Kruft, A History of Architectural Theory from Vitruvius to the Present, 1994, 170. 
Adamska, M. Wendel Dietterlin Starszy: Jego Architectura von Austheilung Z. R. 1598. [Wendel Dietterlin the Elder: His Architecture from Austheilung Z. R. 1598.] Krakowie: PAN i PAN, Recynik Biblioteki Naukovej, Rok XLVIII, 2003.

Alciati, A. Omnia Andreae Alciati Emblemata cum Commentariis, quibus Emblematum Omnium Aparta Origine. [Andrea Alciati Entire Executed Works with Comments, and the Origins of the Same Works.] Antverpiae: Ex Officina Christophori Plantini, Architypographi Regij, 1581.

Blum, H. Ein Kunstreych Buch von Allerley Antiquiteten, so zum Verstand der Funf Seulen der Architectur Gehorend. [An Art Book by Allerley Antiquiteten, so Belonging to the Mind of the Five Pillars of Architecture.] Zurich: Froschower, 1560.

Dietterlin, W. Architectura von Ausstheilung/Symetria und Proportion der Funf Seulen/ und aller darauss volgender Kunst Arbeit von Fenstern/Caminen/Thurgerichten/ Portalen/Bronen und Epitaphien. [Architecture by Parts/Symmetry and Proportion of Five Columns/and from that Subsequent Art Works of Windows/Fireplaces/Door Work/Portals/Fountains and Epitaphs.] Nuremberg: Caymox, Balthasar, 1589.

Forssman, E. Saule und Ornament: Studien zum problem des Manierismus in den Nordischen Saulenbuchern und Vorlageblattern des 16. und 17. Jahrhunderts. [Sun and Ornament: A Study of the Problem of Mannerism in the Nordic Sunflower and Vorlage-Blatter of the $16^{\text {th }}$ and $17^{\text {th }}$ centuries.] Uppsala: Almqvist \& Wiksells, 1956.

Kruft, H. W. A History of Architectural Theory from Vitruvius to the Present. New York: Princeton Architectural Press, 1994.

Kurt, M. "Den Maler, Wendel Dietterlin." [The Painter, Wendel Dietterlin.] In Festschrift fur Karl Lohmeyer. Edited by Karl Schwingel, 14-29. Saarbrücken: West-OstVerlag, 1954.

Mako, V. "Lorenz Stoer and the Metaphor of Creative Power in Architecture." Athens Journal of Architecture 4, no.1 (2018): 65-84.

Ripa, C. Iconologia overo Descrittione di Diverse Imagini Cauate dell'Antichita \& di Propria Invencione. [The Entire Description of Iconology of Different Images Taken from Antiquity and Proper Invention.] Roma: Lepido Faci, 1603.

Rykwert, J. On Adam's House in Paradise: The Idea of the Primitive Hut in Architectural History. Cambridge, Mass.: The MIT Press, 1981.

Skelton, K. "Shaping the Book and the Building: Text and Image in Dietterlin's 'Architectura."' Work \& Image 23, no.1 (2007): 25-44.

St. Augustine. The City of God. $2^{\text {nd }}$ Volume. Edinburgh: John Grant, 1909.

Stoer, L. Geometria et Perspective. [Geometry and Perspective.] Augsburg: Hans Rogel, 1567.

Vredeman de Vries, H. Grottesco in diversche Manieren. [Grotesque in Diverse Manner.] Antwerp: Gerard de Jode, 1560. 